\title{
Correction to: Overview on population screening for carriers with germline mutations in mismatch repair (MMR) genes in China
}

\author{
Min Zhang ${ }^{1}$ and Tianhui Chen ${ }^{2^{*}}$
}

\section{Correction to: Hered Cancer Clin Pract 19, 26 (2021) https://doi.org/10.1186/s13053-021-00182-1}

Following publication of the original article [1], a typesetting errors was identified.

1. The author affiliations were incorrect and have been updated in this correction article.

2. LS-related cancers and MMR mutations in China, paragraph 1 , line 24, the sentence should read: In Pakistan, pathogenic/likely pathogenic MLH1/MSH2 variants account for a large proportion of HNPCC/suspected HNPCC colorectal cancer, mainly including three recurrent variants (MLH1 c.1358dup and c.2041G > A; MSH2 c. 943-1G > C) [17].

3. New reference 17 should be: Rashid MU, Naeemi H, Muhammad N, Loya A, Lubiński J, Jakubowska A, et al. Prevalence and spectrum of MLH1, MSH2, and MSH6 pathogenic germline variants in Pakistani colorectal cancer patients. Hered Cancer Clin Pract. 2019;17: 29.

4. Screening and diagnosing criteria and methods, paragraph 1, line 21 , "hereditary nonpolyposis colorectal cancer" should be deleted and the

* Correspondence: chenth@zjcc.org.cn

${ }^{2}$ Department of Cancer Prevention/Experimental Research Center, Cancer Hospital of the University of Chinese Academy of Sciences (Zhejiang Cancer Hospital), Institute of Basic Medicine and Cancer (IBMC), Chinese Academy of Sciences, Hangzhou, China

Full list of author information is available at the end of the article

sentence should read: Chinese criteria was slightly higher compared to Amsterdam criteria. According to the findings from Fudan University Shanghai Cancer Center (China), for the identification of Chinese HNPCC ...

The original article [1] has been corrected.

\begin{abstract}
Author details
${ }^{1}$ School of Public Health, Hangzhou Medical College, Hangzhou, Zhejiang, China. ${ }^{2}$ Department of Cancer Prevention/Experimental Research Center, Cancer Hospital of the University of Chinese Academy of Sciences (Zhejiang Cancer Hospital), Institute of Basic Medicine and Cancer (IBMC), Chinese Academy of Sciences, Hangzhou, China.
\end{abstract}

Published online: 17 May 2021

Reference

1. Zhang M, Chen T. Overview on population screening for carriers with germline mutations in mismatch repair (MMR) genes in China. Hered Cancer Clin Pract. 2021;19:26 https://doi.org/10.1186/s13053-021-00182-1.

(c) The Author(s). 2021 Open Access This article is licensed under a Creative Commons Attribution 4.0 International License, which permits use, sharing, adaptation, distribution and reproduction in any medium or format, as long as you give appropriate credit to the original author(s) and the source, provide a link to the Creative Commons licence, and indicate if changes were made. The images or other third party material in this article are included in the article's Creative Commons licence, unless indicated otherwise in a credit line to the material. If material is not included in the article's Creative Commons licence and your intended use is not permitted by statutory regulation or exceeds the permitted use, you will need to obtain permission directly from the copyright holder. To view a copy of this licence, visit http://creativecommons.org/licenses/by/4.0/. The Creative Commons Public Domain Dedication waiver (http://creativecommons.org/publicdomain/zero/1.0/) applies to the data made available in this article, unless otherwise stated in a credit line to the data. 